\title{
Principal's Strategy in Developing Competence and Improving Teacher Performance
}

\author{
Damtoro $^{1 *)}$, Nur Ahyani², Nila Kesumawati ${ }^{2}$ \\ ${ }^{I}$ SMP Negeri 25 OKU, South of Sumatra, Indonesia \\ ${ }^{2}$ Universitas PGRI, Palembang, Indonesia \\ *Corresponding author. Email: muhammadkristiawan@unib.ac.id
}

\begin{abstract}
This research is being conducted to find out how the Principal's approach is to develop expertise and enhance the performance of teachers. The goal of this study was to define the Principal's Competence Development Strategy and the Principal's Improving Teacher Performance Strategy. The methodology used in this study is qualitative in terms of data collection methods, including evaluation, interviews and documentation. The data presented using a descriptive approach, the subjects described were the principal and the instructor. The findings of this study suggest that the implementation of the Principal Strategy in the area of competence growth is based on the fact that the Principal involves teachers in seminars, training and workshops with the goal of promoting and improving the competence of teachers. Whereas the main approach on enhancing teacher performance involves coaching teacher performance, monitoring or supervision of teacher performance, promotion of teacher discipline, encouragement and awards.
\end{abstract}

Keywords: Principal Strategy, Teacher Competence, Teacher Performance

\section{INTRODUCTION}

In the new period of globalisation, the growth and development of information technology has promoted high-quality human resources. It is important to know that quality human resources have a major role to play in the growth of all industries, so that it is hoped that the Indonesian nation will be able to stand on an equal footing with other nations. Education is a planned effort in the process of mentoring and learning for individuals to develop and grow into human beings who are independent, responsible, imaginative, intelligent, safe and noble in both the physical and the spiritual aspects. It is understood that the ability of the school principal is responsible for the effective development and performance of teachers across the school learning process and is also responsible for enhancing student learning achievement. Education is the most significant predictor for the growth of a nation [1].

Currently, there are so many teachers who have not met the standards of professionalism as teachers, in compliance with the mandate of Law No. 20 of 2003 on the National Education System and Law No. 14 of 2005 on Teachers and Teachers (UUGD). In the context of the Indonesian community, improving the quality of education is an objective of growth in the national education sector and is an integral part of efforts to improve the quality of the Indonesian people as a whole, in particular by improving the quality of the performance of teachers or educators.

Teachers with full dedication and loyalty aim to direct and cultivate students so that in the future they become useful citizens for the country and the nation. Teachers must be able to improve their performance in such a way that the standard or quality of education in a school is superior. Successful teachers can also produce high-quality students [2]. As far as performance is concerned, there are essentially two things to be seen, namely employee performance (individual) and organizational performance. The inadequacy of an instructor to provide instructional materials during the learning process has an indirect effect on learning outcomes.

The learning process can only be done with the competence of the teacher. Limited knowledge in the distribution of content, both in terms of the use of teaching techniques and other supporting texts, would have an effect on learning outcomes. Various attempts have been made to improve the performance of teachers, namely through the Topic Teacher Deliberation Forum (MGMP), the Teacher Working Group (KKG) and various other training sessions, both in two respective 
fields of research and in other areas that could improve the professionalism of teachers.

Teachers with full dedication and loyalty aim to direct and cultivate students so that in the future they become useful citizens for the country and the nation. Teachers must be able to improve their performance in such a way that the standard or quality of education in a school is superior. As far as performance is concerned, there are essentially two things to be seen, namely employee performance (individual) and organizational performance. The inadequacy of an instructor to provide instructional materials during the learning process has an indirect effect on learning outcomes. The learning process can only be done with the competence of the teacher. Limited knowledge in the distribution of content, both in terms of the use of teaching techniques and other supporting texts, would have an effect on learning outcomes. Various attempts have been made to improve the performance of teachers, namely through the Subject Teacher Deliberation Forum (MGMP), the Teacher Working Group (KKG) and various other training sessions, both in two respective fields of research and in other areas that could improve the professionalism of teachers.

In accordance with Law No. 20 of 2003 Article 3 sets out the roles and goals of education, namely: 'National education aims to develop the ability and character and culture of a nation with integrity, in order to educate the nation, with the goal of improving the potential of students to become faithful and devout human beings. God the Almighty, of noble character, of healthy workforce. The educational institution, in this case the school, is an institution that has a role as a deciding factor in improving quality, because of the red tape associated with the quality of education, the schools serve as executors of all education programs from primary to secondary level. As a specific and dynamic entity to fulfill its vision and mission objectives, schools require reliable human resources. Higher human resources are a deciding factor in the successful and productive accomplishment of organizational objectives. Education is a method for educating the life of a country that is used as a way of creating a whole human being. The progress in education is primarily measured by the quality of its human resources as shown by leaders, students, educators and staff.

There are a variety of variables that decide the success of education, including teachers, education personnel and school principals. Teachers as leaders must be at the forefront in order to increase the standard of education. In the hands of the teacher, a quality learning process will result and produce students who succeed academically, with skills, emotional maturity and skills. The position of teacher is a professional position, that is to say, a position acquired through the course of education and, in particular, training in its area. Teachers are also still expected to improve their profession.

The leadership of the Principal in the execution of its duties must be directed by vision, purpose and priorities, and all tasks to be carried out must be scheduled and included in the School Work Program [3]. The Principal, as the leader of the educational institution, shall serve as the person in charge of all educational activities in the school [4]. The principal, as leader, must also be able to carry out his duties as manager, supervisor, administrator and leader. Schools also need a leader who is willing to work hard to advance the standard of education in the school community they lead [5]. School is not just a place for teachers and students to meet, it is a complex and interrelated structure, and so schools are seen as an institution that needs to be controlled. The core task of the school is to manage human resources that are required to generate highquality graduates according to the needs of society and can contribute to the growth of the nation and the state [3].

The teacher is the key holder of the beauty and efficacy of the learning process, and so the teacher is not only expected to be able to liven up the classroom environment, but also to be able to make learning a process that enhances the personality of students. Competent and professional teachers are able to assume and carry out their duties as students [6]. Modern schooling carries the fate of accountability for destructive developments in the moral and spiritual domain of humanity [7].

\section{METHODS}

This study uses a qualitative analysis approach with descriptive methods, including research that offers a description of quotations from interview manuscripts, field notes, images and records. The data sources (respondents) for this analysis were school principals and teachers. The Principal is a key informant concerned with enhancing teacher competence and improving teacher performance. The use of qualitative data collection methods, consisting of evaluation, interviews and documentation, is basically a main instrument for the researcher.

Qualitative data analysis is carried out where the empiric data is qualitative data in the form of a list of words and not a sequence of numbers and cannot be organized in a classification system. Qualitative research, as stated [8], is a research that has a broad and deep insight into the field of education to be studied and is capable of establishing relationships with anyone in the social situation to be studied. The method used by researchers to analyze data involves three parts, namely, first, data collection and reduction, namely by 
classifying, simplifying, arranging, sorting and disposing of data that is not needed and by triangling or testing the validity of the data. Second, the data are presented in narrative form. Third, draw conclusions from the data provided. The approach method used in this qualitative study is descriptive so that the data presented are in the form of written words and the results of the research [9]. The data collected, evaluated and linked to the theory of the strategy of the Principal in building competence and enhancing teacher performance.

This research was conducted in SMP Negeri 25 Lubuk Raja District, Ogan Komering Ulu Regency, South Sumatra Province.

\section{RESULTS AND DISCUSSION}

\section{Strategies to Improve Teachers' Competence}

The principal of the school is a figure or an example for teachers and staff. The school principal must be able to set a positive example to the school community, one of which is capable of providing direction, guidance and safety. The principal and the instructor were asked these questions in the interview process performed by the researchers. The outcomes of the interviews with the principal and the teacher in the form of questions and answers, as well as the study, were included in the discussion summary. For this cause, teachers with complete commitment and devotion are seeking to direct and inspire students to become useful citizens for the country and the community in the future. The strategy of school principals in educational institutions is closely linked to enhancing the quality of human resources, in particular teachers. Castetter recommends two kinds of methods to enhance human resources, followed by $E$. In his novel, Mulyasa became a vocational school principal, namely a general strategy and a particular strategy. In the general strategy, training workers development must be carried out on the basis of a specific plan of needs, and professional attitudes and skills must be developed in the field of education. A special approach is a strategy that is specifically linked to the creation and enhancement of a more efficient management of the teaching force. These methods are related to healthcare, training, selection, standard of education and career growth [10].

A plan that has been prepared by the school principal really needs to be checked for effectiveness by means of execution, so the principal needs to be assessed, supervised and evaluated and to make frequent changes if the strategy implemented has any flaws. Teachers must be able to improve their performance in such a way that the standard or quality of education in a school is superior. With regard to efficiency, there are essentially two things that can be seen, namely employee performance (individual) and organizational performance. Employee performance is the performance of individuals within an organization, while organizational performance is the entirety of work done by the organization [11].

Research findings in the field are close to the results of Murodah's research in 2017, in this report, that the Principal has a strategy for building competence and improving teacher performance, where the Principal acts as a leader and guides teachers to become competent themselves so that teachers can master and understand competencies and try to enhance their performance. Likewise, the strategy introduced by the head of SMP Negeri $25 \mathrm{OKU}$ aims to build teacher competence and enhance teacher performance by directing and coaching teachers to become competent individuals so that they can understand and master their skills in order to improve performance.

The basic principle of this research is taken from Hamalik's book [12] "Teacher Education Based on a Competency Approach" that a skilled teacher, in carrying out his key tasks and functions and school objectives, is needed to have coherent competence, master teaching materials, to be able to manage the classroom well, to be competent in the use of learning media, to master the foundation of education, to learn. There are many things that the Principal can do to increase teacher performance, including techniques, such as providing feedback on teacher performance and supervision, performing assessments of teacher job processes and outcomes. On the basis of the above definition, it can be said that the principal in the creation of human resources in the school setting, in particular teachers, must carry out planning strategies and policies.

Based on the findings of the interview, the first predictor on the strategy for improving teacher competence is that the teacher wants to enhance his professionalism and the head of SMP Negeri 25 OKU continues to try to inspire teachers to be more interested in studying and reading so that they have a lot of insight.

On the basis of the findings of the data, it can be concluded that the knowledge of the subject teacher about the competence of the teacher and the steps taken to improve the competence of the teacher, namely the competence of the teacher, is a basic basis that must be possessed by each teacher, besides that the competence of the teacher is also laid down in Law No. 14 of 2005 [8] concerning teachers and lecturers, which states that the competence of the teacher is not restricted to the competence of the teacher. Whereas the ability development stage is that a teacher is needed and must have a learning guide, understand and master the material to be taught, and what is no less important is that the teacher must make the Learning Implementation Plan (RPP) a sign for the implementation of teaching and learning activities at school. 
In order to help and inhibit factors in teacher competence development strategy, the results of interviews which, with a good cooperation between teachers, a high level of enthusiasm for carrying out assignments, good material mastery, trustworthiness, responsibility, a high level of work ethic, a willingness to engage in various teacher training and qualification programs are key factors. Although the inhibiting factor does not help the infrastructure of the learning process, there are still teachers who are not able to engage in training exercises and teachers who are not linear in teaching. In order to help and inhibit factors in teacher competence development strategy, the results of interviews which, with a good cooperation between teachers, a high level of enthusiasm for carrying out assignments, good material mastery, trustworthiness, responsibility, a high level of work ethic, a willingness to engage in various teacher training and qualification programs are key factors. Although the inhibiting factor does not help the infrastructure of the learning process, there are still teachers who are not able to engage in training exercises and teachers who are not linear in teaching.

\section{Strategies for Enhancing Teacher Performance}

There are five ways in which principals can enhance the performance of teachers, as Castetter put it, followed by Mulyasa [10] in his book "Becoming a Professional School Principal" namely: 1) the coaching performance of the teacher; 2) supervision of the performance of the instructor; 3) promoting discipline for the staff of education; 4) providing motivation, and 5) giving awards. Based on the findings in the sector, the Principal has introduced a strategy to enhance the performance of teachers at SMP Negeri 25 OKU, namely: (1) carry out the teacher's coaching; (2) carry out daily supervision of learning; 3) disciplinary promotion of educators and education workers; 4) encourage teachers to enhance their results; 5) giving awards to teachers in the form of certificates for the selection of outstanding teachers; 6) provide guidelines for teachers to learn teaching materials; 7) encourage teachers to be able to handle the learning process well; 8) encourage teachers to handle the classroom well; 9) optimize the use of learning media; 10) mastering the National Education Foundation; 12) manage learning experiences; 12) require teachers to measure student learning outcomes; 13) instruct the therapy of teachers to become acquainted with the purposes and services of extension guidance in classroom, and 14) requiring teachers to plan the administration of learning.

Teacher performance is necessary to assess because teachers perform professional duties. Teacher professionalism is the condition, importance and standard of education and teaching skills. Professional teachers are teachers who are skilled, knowledgeable and willing to increase student performance and who are able to influence student teaching and learning processes [5].

The role of teachers in developing competence must pay attention to problems relating to the management of teaching and learning interactions, in relation to this, from the results of interviews with school principals, researchers found that most of the teachers of SMP Negeri 25 OKU have mastered the teaching materials used in class, including being able to manage the class well, be able to manage the teaching and learning process, use the media as a learning resource, master educational foundations, manage learning interactions and assess student achievement for teaching purposes [13].

The role of teachers in the development of skills must pay attention to problems related to the management of teaching and learning experiences, in relation to this, from the results of interviews with school principals, researchers have found that most of the teachers of SMP Negeri 25 OKU have mastered the teaching materials used in the classroom, including the ability to manage the classroom well. In order to improve the performance of teachers, the principal must practice oversight (supervision) and promote a disciplined attitude towards teachers, in particular selfdiscipline. Based on the findings of the study, it has been found that the approach adopted by the Principal in terms of supervision or supervision of learning has been shown to increase the performance of teachers in SMP Negeri 25 OKU. Discipline instruction often needs to be offered by the Principal in order to increase teacher performance, and this has been achieved by direct supervision of teacher attendance and monitoring of attendance.

\section{CONCLUSION}

The Principal's strategy for developing competencies and improving teacher performance at SMP Negeri 25 OKU concluded that the strategy used by the Principal in developing teacher competence was to improve teachers' ability to master the learning process and to enable teachers to read reference books more frequently so that they have many insights into understanding science. In addition, the school principals also have teachers at educational conferences, Subject Teacher Deliberation Forum (MGMP) and Training Education (DIKLAT) as an attempt to advance the competence of teachers.

\section{AUTHORS' CONTRIBUTION}

Damtoro: designed and performed experiments and analysed data. Nur Ahyani and Nila Kesumawati: proofing and correcting. 


\section{ACKNOWLEDGMENTS}

Our deepest gratitude goes to Teachers SMP Negeri 25 Lubuk Raja District, Chancellor of Palembang PGRI University, Director of the Postgraduate Program of PGRI Palembang University and the Education Management Study Program of PGRI Palembang University, who have supported us in doing this extraordinary thing. This project is funded independently. We also want to thank our Education Management friends who helped us a lot in a short time frame to complete this project.

\section{REFERENCES}

[1] Agustina, M., Kristiawan, M., \& Tobari. (2021). The Influence of Principal's Leadership and School's Climate on The Work Productivity of Vocational Pharmacy Teachers in Indonesia. International Journal of Educational Review 3(1), 63-76.

[2] Hanim, H., \& Rahmadoni, J. (2020). Determination of Lecturer Reception Using Analytical Hierarchy Process (AHP). Journal of Applied Engineering and Technological Science (JAETS), 1 (2), 136141.

[3] Tim Penyusun Undang-Undang Nomor14 Tahun 2005 tentang guru dan dosen [The Law Drafting Team Number 14 of 2005 on teachers and lecturers].

[4] Agustina, M., Kristiawan, M., \& Tobari. (2021). The Influence of Principal's Leadership and School's Climate on The Work Productivity of Vocational Pharmacy Teachers in Indonesia. International Journal of Educational Review 3(1), 63-76.

[5] Hayati, R. (2019). Kepemimpinan Kepala Sekolah dalam Meningkatkan Kinerja Guru [Principal Leadership in Improving Teacher Performance]. Jurnal UPGRI Palembang.

[6] ] Fitria, H., Kurniawan, M., \& Rahmat, N. (2019). Upaya Meningkatkan Kompetensi Guru Melalui Pelatihan Penelitian Tindakan Kelas [Efforts to Improve Teacher Competence through Classroom Action Research Training]. Jurnal Abdimas Unwahas UPGRI Palembang.

[7] Maseleno, A., Ayshwary, B., Ivanova, T. N., Hashim, W., Nguyen, P. T., Shankar, K., Kristiawan, M., Huda, M. (2019). General Theoretical and Philosophical Aspects of Modern Education. Aspectos Teóricos y Filosóficos Generales de la Educación Moderna. Revista San Gregorio 2019, No. 32 Special Issues August
[8] Tim Penyusun Undang-Undang Nomor 20 Tahun 2003 [Team Drafting Law Number 20 Year 2003].

[9] Lian, B. (2017). Proses Pengambilan Keputusan Kepala Sekolah Terhadap Kinerja Guru SMP [Principal Decision Making Process on Junior High School Teacher Performance]. Jurnal Manajemen Kepemimpinan dan Supervisi Pendidikan UPGRI Palembang.

[10] Mulyasa, E. (2007). Menjadi Kepala Sekolah Profesional [Become a Professional School Principal]. Bandung: PT. Remaja Rosda Karya

[11] Fattah. A. H. (2019). Kepuasan Kerja dan Kinerja Pegawai [Job Satisfaction and Employee Performance]. Yogyakarta: Elmatera.

[12] Hamalik, O. (2004). Pendidikan Guru Berdasarkan Pendekatan Kompetensi [Teacher Education Based on a Competency Approach.]. Jakarta: Bumi Aksara

[13] Sugiyono. (2010). Metode Penelitian Kombinasi [Combination Research Methods]. Bandung: Alfa Beta 